\title{
SEMIOTIC ANALYSIS OF HOTEL ADVERTISEMENT
}

\author{
Km Tri Sutrisna Agustia \\ Universitas Dhyana Pura \\ trisutrisna@undhirabali.ac.id
}

\begin{abstract}
The phenomenon of miss-interpretation and the mismatch of the desired meaning in a hotel advertisement gives significant losses to hoteliers in Bali. The purpose of this study is to understand the meaning contained in a hotel promotion advertisement. This study aims to align the problem of conveying a meaning in promotional advertisements that are often not understood by tourist targets so that there is a misunderstanding between the wishes of the hotel marketing and the needs of the tourists themselves. This study analyzes (1) ads part segmentation, (2) describes the relationship between signs in the form of markers and signs in hotel advertisements, (3) describes and provide an overview of suggestions regarding the role of the proper meaning in hospitality advertisements. The design of this study uses a qualitative design collected from study subjects in the form of hotel advertisements collected from promotional advertisements (brochures or websites) of hotels in Bali. The objects in this study are in the form of words, phrases, sentences and images in the advertisements. The study stage begins with data collection on hotel advertisements as regarding to the advertisements being promoted. Then a picture of the proper meaning of promotional advertising based on semiotics will be drawn up. The results achieved are the connection between symbols and meanings used in a hotel promotion advertisement. Semiotic science variables can be added in the design of a hotel advertisement so that it provides an illustration of the suitability between the application of semiotics and hotel marketing practices as outlined in the advertisement. The exact match between the desires and the meaning to be conveyed can be developed properly to avoid misunderstandings between the hotel and the target market.
\end{abstract}

Keywords: advertising; Bali; hospitality; promotion; semiotics

\section{INTRODUCTION}

Tourism, if viewed instrumentally, is a mechanism that becomes an economic leveraging tool that substituting traditional and natural aspects into profitable matters because of their nature. The primary issue that seems, by all accounts, to be tested is, the "nature" of the hotel industry commercialization that hotel industry resources rely intensely upon the social and representative universe of a place. As such, the hotel industry products and enterprises are items that can barely be envisioned without an exceptional socio-social living space. Agricultural nations depend intensely on the hotel industry to offset financial improvement with created nations. As indicated by the Indonesian Ministry of Tourism, the all out effect of the Hotel and Tourism area is demonstrated to have contributed $10.4 \%$ of worldwide GDP and 313 million positions, or
$9.9 \%$ of absolute work in 2018. On the business side, the hotel industry positions second, After the public area with the expansion of around 2 million positions as per the all-out number of unfamiliar guests up to 15.8 million out of 2018. This examination depicts that the nation's hotel industry advancement methodology will in general feature theoretical resources, for the most part emblematic, to increase monetary advantages. Thusly, the hotel industry rivalry, as an additional layer, is occurring among the qualities that separate the contenders. Writing proposes that hotel industry itself is a business that gives representative products and enterprises to customers looking for common ceremonies (Hummon, 1988). The contribution and advancement of this emblematic utilization is organized in the perspective of hotelers. The acceleration of mass the hotel industry creates a far reaching marvel, called vacationer look, to 
instruct and train current sightseers about what to see and how to see things orchestrated their satisfaction. The association around this vacation destination should be elevated to get hotelers from everywhere the world. The allure of the hotel industry has an advertising and advancement procedure to increase a spot on the lookout. Having just a bunch of hoteler resources (common, social, and so on) isn't adequate to pull in sightseers and strategies for invigorating vacationer consideration are conspicuous. The accompanying issues are the opposition between the hotel industry objections. Product quality isn't just adequate for the hotel industry promoting. Moreover, certain objections rival others regarding encounters and semantic universes. This is the striking part of a product: an objective ought to contend with others as a glorified vacation spot (Chatelard, 2008). The particular character of a hotel industry objective can at times turn into a social resource. These resources comprise of cooperations with hotelers and changes as expected. To put it plainly, the hotel industry area presents striking highlights in the quest for a social development. There are a few focal points for the present hotelers to know ahead of time about vacationer locations. This gives an occasion to sightseers to assess their inclinations by contrasting between objections dependent on financial standards and social tastes. This overall portrayal must be finished by possible vacationers through the hotel industry materials/markers/pointers (films, hotel guides, photographs, banners/flags, leaflets, web journals, articles, and so forth) Visual or/and sound substance comprises of solid qualities as well as of theoretical qualities. Dynamic qualities are orchestrated through the communication among signs and images, as such markers and markers. Inside this system, objections additionally wind up in different parts of representative rivalry. There are a few preferences for the present sightseers to know ahead of time about hoteler objections. It gives an occasion to hotelers to assess their inclinations by contrasting between objections dependent on financial measures and social taste. This overall portrayal must be finished by likely sightseers through the hotel industry materials/markers/pointers (films, hotel guides, photographs, banners/pennants, handouts, online journals, articles, and so forth) Visual or/and sound substance comprises of solid qualities as well as of dynamic qualities. Theoretical qualities are organized through the connection among signs and images, at the end of the day markers and markers. Inside this system, objections likewise end up in different parts of representative rivalry. While advancing objections under ceteris paribus (in no way different) and thinking about rivalry at an emblematic level, apparently contenders have a solitary methodology: elevating to their objective sightseers, the ones generalized by the objective entertainer. The advancement at that point works on a progression of representative encounters.

A series of studies was conducted by several researchers who used semiotics to analyze advertisements. Previous studies are given to show the similarities and differences between this study and other studies. These studies have been reviewed and the results of previous studies are presented as follows: The first is taken from A'la (2011) in his study A Semiotic on the A-Mild Advertising using Roland Barthes' theory to try to find out the verbal and nonverbal connotations in A-Mild cigarette advertisements. Not only verbal signs but also colors were analyzed in this study. In this study he only analyzed the colors, not the images. He analyzed the ad using Roland Barthes' theory. The current study analyzes advertising more deeply and focuses solely on audio as well as visual material. In addition, taken from Syahrani (2011) in his thesis Summary of a Semiotic Analysis on Chocolate Advertisement in Style Magazine tries to analyze the relationship between the object and the interpretation of ants on Toblerone, 100 calorie Nabisco milk chocolate and dove chocolate with peanut butter. He found a connection between the meaning and the hidden message to be conveyed (Syahrani, 2011). Syahrani used Charles Sander Pierce's theory to analyze the ad. The current study only focuses on a single advertisement, even though it is believed that the advertisement being analyzed can provide a lot of information. Another previous study, Conducted a study on markers, tagging, and denotation of connotations in Meme Troll Football (Laksono, 2016). This study explores the meaning of several phrases 
and sentences that appear in the data. The writer uses Roland Barthes' theory and Saussure concept to analyze the data. The current study focuses on both audio and visual material consisting of more complex advertising elements.

For instance, ideas that stick out innovation, sentimentality, and hotel insight are utilized to develop reality and give hotel encounters. Amariou (2000) contends that if the objective needs inventiveness, the hotel industry becomes possibly the most important factor to deliver it (mimicking untamed life and country life, and so on). The movement experience at that point changes itself into a legitimate and utopic experience contingent upon the aggregate encounters of the predecessors and history that nobody can recollect. To put it plainly, rivalry creates from a genuine geography to a representative geology wherein utilization is emblematically obliged. Representative utilization encounters (Y. et al., 2013) resemble games. It is a comprehensive methodology comprising of pleasantries that urge sightseers to satisfy their own requirements while present day hotelers (MacCannell, 1973) keep away from their "genuine figures". In light of these suspicions, a system is expected to comprehend designs that oblige the multiplication and showcasing of these hotel industry implications. Attention to the prerequisite for inspecting a wide range of the hotel industry advancement materials that serve this cycle (Echtner, 1999). Along these lines, this investigation receives a semiotic examination to depict the concealed implications in accommodation ads in Bali. The data in this study were taken through the hotel promotion advertisement. This data was chosen because it has significant marker and marker elements in an advertisement. In the study, the following questions were discussed: a) What do the symbols on the promotional ads mean? b) What is the role of semiotics in the promotion of tourism destinations in increasing tourist visits?

\section{METHOD}

The data is taken from some hotel advertisements regarding hotel promotions in Bali. This advertisement contains various symbols both in the form of images and writings that contain certain meanings. Download ads were taken from the website and used in this study. These advertisements were chosen as data sources because they contain interesting verbal and visual cues to analyze. There is a tendency that the use of signs in this type of advertisement is different from the promotional advertisements for hotels in Bali.

Data were collected by means of observation and note-taking techniques, and data was also collected through online research. The analytical method used is verbal and visual communication semiotics which basically operates on two levels of analysis. First, analysis of signs individually, including: signs, codes, and sign meanings. Second, analyze the signs that make up the text. The data collected were analyzed qualitatively based on Barthes theory. The Barthes-based Saussure semiotic examination hypothesis characterizes a phonetic sign on different sides of an element, on the sign it is called Signifier while the opposite side is called Signified. Signs are the entire material part of signs a lot is the psychological idea of signs (Barthes, 1974). The two things that are indivisible from the Signified (material viewpoints) and the Signifier (mental ideas) are clarified as follows:

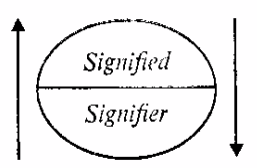

\section{DISCUSSION}

These three parts represent a combination of Signified and Signifier. These parts are the ad segmentation of the entire promotional advertisement.

Data 1

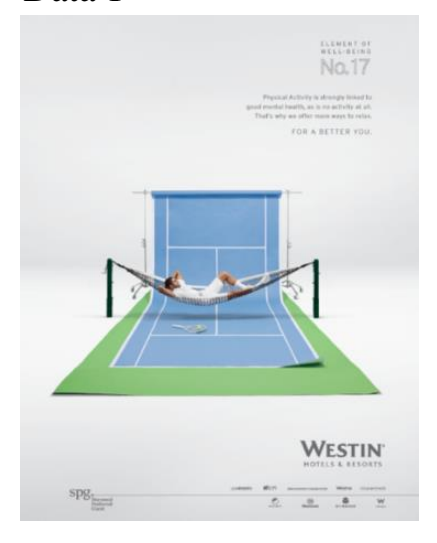


Table 1. Visual and Verbal

\begin{tabular}{|c|c|c|}
\hline Sign & Signifier & Signified \\
\hline \multirow[t]{2}{*}{$\begin{array}{l}\text { Verbal: } \\
\text { Text }\end{array}$} & $\begin{array}{l}\text { Physical activity } \\
\text { is strongly } \\
\text { linked to mental } \\
\text { health, as is no } \\
\text { activiy at all. } \\
\text { That why we } \\
\text { offer more ways } \\
\text { to relax }\end{array}$ & $\begin{array}{l}\text { An encouragement } \\
\text { to the guest when } \\
\text { they visit their hotel } \\
\text { to relax and still } \\
\text { doing their physical } \\
\text { activity. }\end{array}$ \\
\hline & $\begin{array}{l}\text { FOR BETTER } \\
\text { YOU }\end{array}$ & $\begin{array}{l}\text { This phrase giving } \\
\text { a guarantee when } \\
\text { stay at the hotel, } \\
\text { will give a } \\
\text { satisfaction of } \\
\text { better experiences. }\end{array}$ \\
\hline $\begin{array}{l}\text { Visual: } \\
\text { Picture }\end{array}$ & $\begin{array}{l}\text { Man lie down on } \\
\text { the tennis net at } \\
\text { the the tennis } \\
\text { court. }\end{array}$ & $\begin{array}{l}\text { Showing one of } \\
\text { physical activity } \\
\text { (tennis) but the } \\
\text { guest can feel relax } \\
\text { as the doing } \\
\text { nothing. }\end{array}$ \\
\hline
\end{tabular}

This ad shows a message that matches the tagline Physical activity is strongly linked to mental health, as is no activiy at all. That why we offer more ways to relax. This tagline shows the impression that when guests stay at the hotel, the hotel provides various facilities that support guests' activities at the hotel, including physical activities such as sports (eg. tennis), but guests can still feel the relaxed atmosphere they feel like staying in a hotel. The tagline also emphasizes that even though guests stay at the hotel, they can still carry out activities to maintain their health and at the same time feel the comfort they should get while staying at the hotel. And that tagline FOR BETTER YOU indicating the service guarantee that the hotel provide for any guest regarding to the best stay experiences in the hotel.

\section{Data 2}

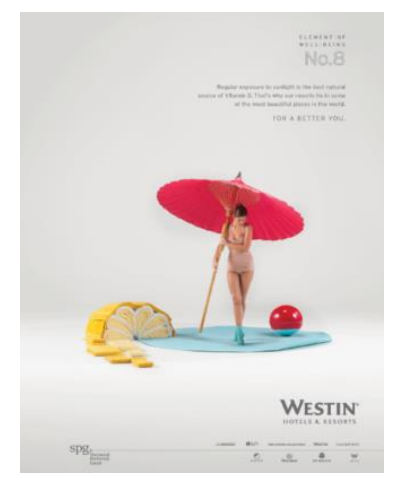

Table 2. Visual and Verbal

\begin{tabular}{|c|c|c|}
\hline Sign & Signifier & Signified \\
\hline $\begin{array}{l}\text { Verbal: } \\
\text { Text }\end{array}$ & $\begin{array}{l}\text { Regular exposure } \\
\text { to sunlight is the } \\
\text { best source of } \\
\text { vitamin D. That's } \\
\text { why our resort lie } \\
\text { in some of the } \\
\text { most beautiful } \\
\text { places in the } \\
\text { world. }\end{array}$ & $\begin{array}{l}\text { A simple } \\
\text { information } \\
\text { about the } \\
\text { hotel } \\
\text { location (in } \\
\text { this case, in } \\
\text { the tropical } \\
\text { location). }\end{array}$ \\
\hline $\begin{array}{l}\text { Visual: } \\
\text { Picture }\end{array}$ & $\begin{array}{l}\text { Woman bring a } \\
\text { red umbrella, } \\
\text { surrounded by } \\
\text { towel (in form of } \\
\text { orange), beach } \\
\text { ball (in form of } \\
\text { cherry) and blue } \\
\text { mattras (in form of } \\
\text { beach water) }\end{array}$ & $\begin{array}{l}\text { Indicating } \\
\text { location of } \\
\text { the resort in } \\
\text { the tropical } \\
\text { area }\end{array}$ \\
\hline
\end{tabular}

This advertisement shows information about the location of the hotel. The location indicated by the tagline Regular exposure to sunlight is the best source of vitamin D. That's why our resort lie in some of the most beautiful places in the world. Through this tagline, the hotel aims to introduce their hotel chain, which is extensive and ubiquitous. Not only in areas that have certain climates, but in various locations with different climates. In this advertisement, the hotel aims to show the location of the hotel in a tropical climate. In the visual used, it shows a woman carrying a sun umbrella that indicates a sun area that is identical to the location of a tropical climate. In addition, it is also equipped with several visuals of beach balls and towels arranged in a way that resembles tropical fruits.

Data 3

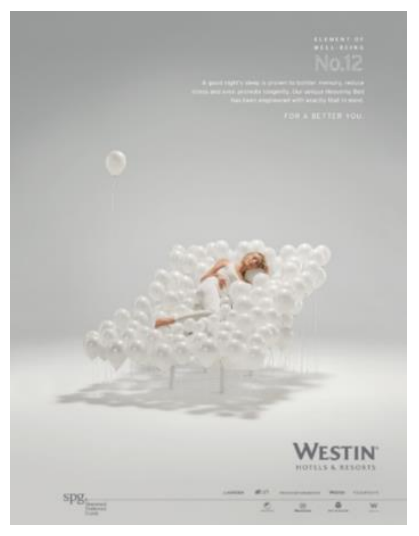


Table 3. Visual and Verbal

\begin{tabular}{cll}
\hline \multicolumn{1}{c}{ Sign } & \multicolumn{1}{c}{ Signifier } & \multicolumn{1}{c}{ Signified } \\
\hline Verbal: & $\begin{array}{l}\text { A good night's } \\
\text { sext } \\
\text { bolster memory, } \\
\text { reduce strees and } \\
\text { even promote } \\
\text { longevity. Our } \\
\text { unique heavenly } \\
\text { bed has been } \\
\text { engginered with } \\
\text { exactly that in } \\
\text { mind. }\end{array}$ & $\begin{array}{l}\text { A simple } \\
\text { information about } \\
\text { the hotel room's } \\
\text { facilities. For } \\
\text { spesifically the } \\
\text { hotel beds. }\end{array}$ \\
\hline Visual: & $\begin{array}{l}\text { Woman sleep on } \\
\text { Picture }\end{array}$ & $\begin{array}{l}\text { Showing balloons } \\
\text { comfortable sleep, } \\
\text { like drifting sleep } \\
\end{array}$ \\
& & on the balloons. \\
\hline
\end{tabular}

This part of the advertisement shows the room facilities owned by the hotel. This facility is devoted to the room facilities that are owned. The hotel shows its facilities supported by the tagline $A$ good night's sleep is proven to bolster memory, reduce strees and even promote longevity. Our unique heavenly bed has been engginered with exactly that in mind. This tagline gives the impression of how the mattress that is owned in a hotel room has been designed in such a way for the comfort of the guests. It is likened that guests will have a feeling like sleeping very comfortably as if sleeping on a pile of floating balloons. This is also supported by pictures that give an idea of how comfortable guests will experience when they stay at the hotel.

The branding section is represented by symbols in promotional advertisements. The promotional ad above uses an index image. These ads have the ability to be the most attractive visual representation. Indexical images are direct connections of two related objects or concepts. There are many different ways to use a semiotic approach to advertising, each with its own goals in terms of storytelling as well as connecting with audiences at various levels. From the utilization of more direct and cleaner photography to the utilization of dubious and provocative pictures (and normally insignificant content), these classes are utilized independently, just as in coordinated effort, to make something intriguing and should be viewed as when considering everything. Message attempting to be conveyed. The key is to think about the crowd, what they worth, and how to make an interpretation of those qualities into significant visuals. In promoting and publicizing correspondences, semiotics assumes a vital part in deciding the achievement or disappointment of any undertaking. Through the compelling use of verbal, visual and performative components (activities by purchasers), organizations can reinforce their span to their clients. These representative components incorporate logos, ceremonies, social images, colors, notable people, text, notices, sites, actual climate, neighborliness and administrations, slogans, and other touch focuses. From the hotel advertisements, it can be seen that the use of symbols has met the achievement of useful, precise and appropriate advertising for the purpose of the promotional advertisement being made.

\section{CONCLUSION}

This examination is an endeavor to portray the manner in which Indonesians challenge emblematic rivalry. It was discovered that the hotel industry technique depends on compromise of Western qualities, for example, innovation, comfort and Eastern qualities: neighborliness, everlasting status, exoticism, and so forth The hotel industry advancement notices as of now feature nearby tones that situate Indonesia naturally (in this examination: Bali). This kind of advancement, whenever viewed as an unmistakable and non-solid the hotel industry structure, has a few disadvantages in the period of representative rivalry. The material being studied needs to be improved with the contribution of authorities. If tags and markers are well synchronized, these aspects can provide a good overall understanding of the meaning and purpose of the promotional advertisement. In this study, it was discovered how the hotel has designed their advertisement in the best and most detailed way possible to give an unforgettable impression to potential guests and their guests. How the hotel has compiled various images and verbally and visually to give a deep impression to their guests and potential guests.

In addition, the application of semiotics is very helpful in hotel promotion efforts. Semiotic can be used as a study to determine the 
direction of hotel promotion. As part of the branding indicated by symbols in promotional advertising. The promotional ad above uses an index image. These ads have the ability to be the most attractive visual representation. And also as a support to increase the reach of the hotel to guests and potential guests. Through the viable utilization of verbal, visual and performative components, organizations can fortify their span to their clients.

\section{REFERENCES}

Barthes, R. (1974). Mythologies. Wang.

Chatelard, G. (2008). Tourism and Representations of Social Change and Power Relations in Wadi Ramm Southern Jordan.

http://hal.archivesouvertes.fr/docs/00/33/

84/46/PDF/Tourism_and_representations .pdf

Echtner, C. (1999). The Semiotic Paradigm:
Implications for Tourism Research. Journal of Tourism Management, 20, 4757.

Hummon, D. M. (1988). Tourist Worlds: Tourist Advertising, Ritual, and American Culture. The Sociological Quarterly, 29(2), 179-202.

Laksono, W. P. (2016). A Semiotic Analysis in Meme "Troll Football. State Islamic University of Sunan Ampel Surabaya.

MacCannell, D. (1973). Staged Authenticity: Arrangements of Social Space in Tourist Settings. The American Journal of Sociology, 79(3), 589-603.

Syahrani, S. F. (2011). Summary of A Semiotics Analysis on Chocolate Advertisements in Style Magazine. State Islamic.

Y., E., E., S.-T., \& S, P. (2013). Symbolic Consumption of Tourism Destination Brands. Journal of Business Research 66, 711-718. 